\title{
Mammals diversity of mount sawal wildlife reserve, Ciamis, West Jawa
}

\author{
Eko Sulistyadi* \\ Museum Zoologicum Bogoriense, Research Center for Biology. Cibinong Science Center, Jl. Raya Jakarta-Bogor Km. 46, \\ Cibinong, Indonesia, 16911
}

\begin{abstract}
We conducted research on mammals diversity in the Mount Sawal Wildlife Reserve on March 2012. Data collection was obtained by direct observation and interviews. They are includes direct encounters, traces/signs of the mammals presence (ex: faeces, traces/footprints, odors, scratch marks, food scraps, etc.) as well as information from the community around the forest. Observations were carried out in seven observation path/forest block in Mount Sawal namely Belandongan, Cibaruyan Jero, Gintung, Gunung Luhur, Kigugula, Jamikuwu, and Sawah Gunung. We documented at least 10 species of mammals have been recorded, including Panthera pardus melas, Presbytis comata, Trachypithecus auratus, Macaca fascicularis, Muntiacus muntjak, Hystrix javanica, Aonyx cinereus, Prionailurus bengalensis, Mydaus javanensis, and Sus Scrofa. The existence of mammals is relatively evenly distributed in all observation path/forest block in The Sawal Mountain. Six species are protected by Indonesian Law, including Panthera pardus melas, Presbytis comata, Trachypithecus auratus, Muntiacus muntjak, Hystrix javanica, and Prionailurus bengalensis. Information on the diversity of mammals is expected to be a scientific consideration in the management area of the Mount Sawal Wildlife Reserve.
\end{abstract}

\section{Introduction}

Mount Sawal Wildlife Reserve was designated as a conservation area based on Decree of the Minister of Agriculture No. 420 / Kpts / Um / 1979 with an area of 5,400 Ha. This area covers 6 sub-districts in Ciamis Regency, namely Panjalu, Kawali, Cipaku, Cikoneng, Cihaurbeuti, Sadananya, and Panumbangan. The Sawal Mountain area has a hilly topography, with the highest peak of 1,764 m. asl. Sawal Mountain is the upstream of the Citanduy river and is a water catchment area for the Regencies of Ciamis, Tasikmalaya and the surrounding area. Gunung Sawal has a strategic position in the context of the conservation of biological resources and its function as a life support system. Its location which is between the residential areas in the regencies of Ciamis and Tasikmalaya makes its role and function very important for people's lives. This is in accordance with Junaidi \& Maryani [1] who stated that the Citanduy watershed has an important role in maintaining the preservation of water resources that are important for the community while helping to preserve nature, including the animals in the vicinity. Related to this position, Gunung Sawal has an important role and function in providing environmental services and life support systems.
Sawal Mountain is a rainforest ecosystem with a high diversity of flora and is an important habitat for various animals in West Java, especially mammals. Mammals are taxa groups that have important ecological roles and functions in ecosystems, so their existence must be conserved. Some important roles of mammals in ecosystems include pollination, seed dispersers, soil fertilizers, and natural predators. Associated with species conservation and area management, the disclosure of data and information on biodiversity especially mammals is very important. Furthermore, Cardillo et al [2] state that mammals tend to be vulnerable to extinction due to habitat destruction and fragmentation as well as low reproduction rates so it is urgent and important to examine their presence and role in their habitat.

One important factor in the management area is the availability of basic biodiversity data. Data and information on species diversity and biological aspects are important factors to identify species structure in the community which can then be used as a basis for determining management priorities [3]. Furthermore, Sulistiyadi [4] stated that data on the diversity and distribution of large mammals are important basic information in conservation management plans. Related to this, an effort is needed to provide it, one of which is research related

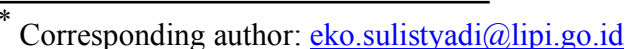


to the diversity and distribution of mammals in the Mount Sawal Wildlife Reserve.

\section{Material and Methods}

Research on mammals diversity in the Mount Sawal Wildlife Reserve was carried out in March 2012. Data collection was carried out using a direct observation (field survey) combined with information gathering through interviews. Data collected includes mammal species encounters, coordinates points, time of encounters, mammals' presence/traces (ex: feces, footprints, feed remains, claw marks, etc.). This method is effective for diurnal and nocturnal mammals and is very helpful in knowing the presence of large mammals, primates and carnivores [5]. Observed mammals are identified based on morphological characters refer to Corbet \& Hill [6] and Payne et al [7]. As supporting information, interviews and literature searches were also conducted. Interviews were conducted with residents around the forest to explore further information about the existence of mammals at the study site (Fig. 1). Field observations were carried out using the line transect method by exploring following the paths on seven observation path/forest block in Sawal Mountain, including Belandongan, Cibaruyan Jero, Gintung, Gunung Luhur, Kigugula, Jamikuwu, and Sawah Gunung. Field observations using tools such as binocular, digital cameras, Garmin GPS, and stationery to record data. The data obtained were analyzed descriptively and presented with graphs and diagrams to illustrate the composition and distribution of mammals species in Sawal Mountain. Besides, the diversity index analysis was also done with PAST Software ver. 4.0 [8].

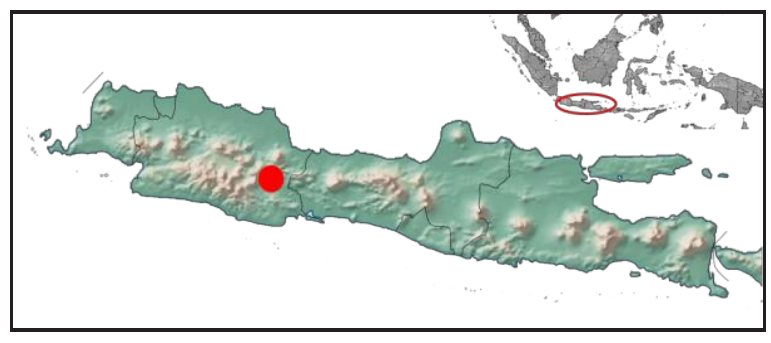

Fig. 1. Map of research sites on Mount Sawal Wildlife Reserve

\section{Results and Discussion}

\subsection{General Condition of Research Location}

Mount Sawal Wildlife Reserve is a conservation area in Ciamis Regency, West Java, which has an area of 5,400 hectares and covers 9 districts, namely Panjalu, Kawali, Cipaku, Cikoneng, Cihaurbeuti, Sadananya, Lumbung, Sindangkasih, and Panumbangan. Astronomically, it is located between $7^{\circ} 15^{\prime}$ latitude and $180^{\circ} 21^{\prime}$ longitude. The peak of Sawal Mountain at 1764 meters above sea level (m asl) is still surrounded by dense forest, with an average slope between $20-45 \%$. In this area flows Citanduy river with its tributaries, namely Cibaruyan, Cipalih, and Ciguntur rivers.

The climatic conditions in the Sawal Mountain are type $\mathrm{B}$ according to Schmidt and Ferguson classification, the average rainfall is $3,360 \mathrm{~mm}$ per year, the temperature ranges between $19^{\circ}-27^{\circ}$ Celsius. Most of this area is natural forest $( \pm 95 \%)$ and the rest is planted forest. Tree species found in natural forests include Artocarpus elasticus, Schima walichii, Castanopsis argantea, Quercus sp, Ficus sp. and Podocarpus imbricatus, while on plantations are Pinus merkusii, Agathis lorantifolia, Switenia mahagoni, Altingia excelsea, and Caliandra sp. This area is also a habitat for various species in West Java, especially mammals [9]. Currently, Sawal Mountain is designated as a conservation area which serves to maintain the hydrological function as well as to conserve biological resources. This shows the importance of Sawal Mountain area as a wildlife reserve [9].

\subsection{Mammal Community of Mount Sawal Wildlife Reserve}

Observations recorded that at least 10 mammal species were found on Mount Sawal Wildlife Reserve (Fig. 2). Family Cercopithecidae is the most common with 3 species (30\%), namely Trachypithecus auratus, Presbytis comata, and Macaca fascicularis. The occurrence of primate species is closely related to the forest condition of Sawal Mountain.

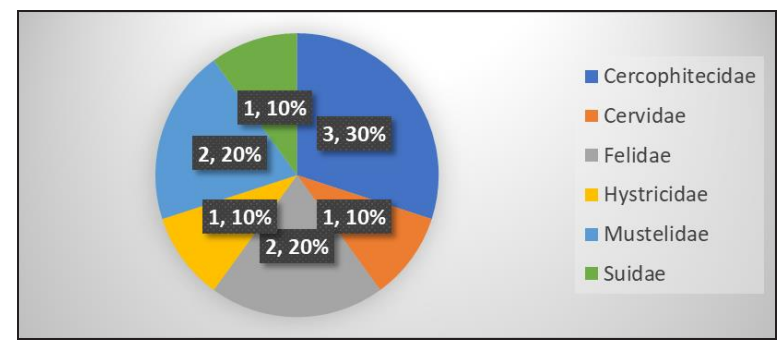

Fig. 2. Composition of family and species of mammals that exist on Sawal Mountain

Based on composition, the mammal community in Sawal Mountain consists of 6 families and 10 species is relatively lower compared to the mammal community on Mount Slamet (10 families; 15 species). Most of the recorded mammals in Sawal Mountain belong to the primate and carnivorous orders, but also found the artiodactyla and rodentia orders. This composition is relatively the same as the mammal community on Slamet Mountain, Central Java [10]. The similarity of the mammal community in both locations is influenced by the similarity of ecosystem characteristics which are the remaining mountainous tropical rain forest on Java Island. Based on Husodo [11] it is known that the number of mammals recorded in West Java is 54 species, 21 
families, and 9 orders. This data seems contrasted, but in certain families, for example, primates are relatively not much different $(60 \%$ representation). Furthermore, six species in Sawal Mountain are always found in all study locations in West Jawa were conducted by Husodo [11], including $P$. pardus, $P$. bengalensis, T. auratus, $P$. comata, A. cinereus, and S. scrofa.

Based on activities, 3 species are diurnal, 3 species are nocturnal, and 4 other species active during the day and night, meanwhile based on its strata 3 species are arboreal and 7 species are terrestrial. A complete list of species is presented in Table 1. Field observations show that primate species are often found through voice and visual contact, meanwhile the species of artiodactyla and carnivores are more commonly found through footprints, feces, traces, food scraps, and information from local society. This is related to the biological characteristics of mammals and influencing habitat factors. Primates that are more arboreal and also often voiced have a higher likelihood of being seen and heard. As stated by Purbatrapsila [12] that M. fascicularis is more active in trees than at ground, in which dominant activities are moving, eating, and resting. On the other side, carnivores and artiodactyla are usually more sensitive to human presence and their terrestrial nature makes it difficult to be seen in dense forests. Besides that, environmental factors such as slope and forest density also affect the distribution and encounter of mammals. Susanti [13] states that the most influential factor in the presence of mountain goats in Kerinci Seblat National Park is the slope and distance from the edge of the forest.

Mammal species on Sawal Mountain are relatively evenly distributed in each observation path/forest block, except at Kigugula and Sawah Gunung where there are only two species each location. At the Kigugula only $P$. bengalensis and $A$. cinereus were found, while at the Sawah Gunung there were $T$. auratus and $P$. comata (Fig. 3). The distribution of mammals is closely related to the availability of feed sources. Primates are more often found in forest habitats with fairly dense trees that provide shelter and food. Herbivorous animals will be more common in forest areas and forest edges that are rich in the understorey. Evenly distribution of mammals shows that Sawal Mountain still has a good habitat condition and carrying capacity for various species. Furthermore, the presence of mammals from various trophic levels, including producers, consumers and top predators, shows that ecosystem balance is still good. This condition needs to be maintained because it has direct implications for the ecosystem balance and life support system that is very important for the surrounding community.
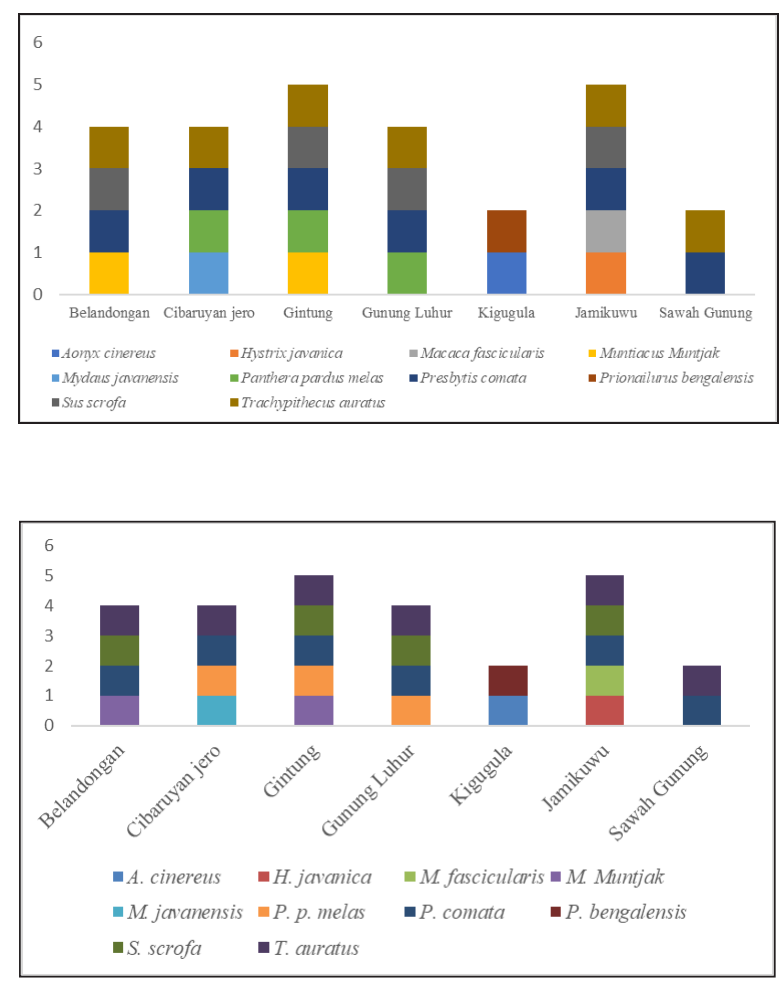

Fig. 3. Distribution of mammals in Gunung Sawal

Based on distribution and abundance shows that $T$. auratus, $P$. comata, and S. Scrofa have the highest frequency of encounters during observation (Fig. 4). Whereas $P$. pardus and $M$. muntjak are relatively rare because they are sensitive and prefer in the forest habitats and higher altitudes. Thus the distribution of mammals on Sawal Mountain depends on the characteristics and behavior of animals and is also influenced by habitat conditions and environmental factors at each location. This is in line with Maharadatunkamsi [14] stated that the existence of small mammal species in Citanduy Watershed is related to the type of habitat and environmental factors that exist in that location.

Based on altitude, more mammals are found in the range of 700 to $1000 \mathrm{~m}$. asl. (Fig. 5). This pattern is the same as the mammal community on the southern slopes of Slamet Mountain which is concentrated on 700-900 m. asl, but different from the eastern side of Slamet Mountain which is high on the range of 1,700$2,200 \mathrm{~m}$ asl [10]. This is influenced by the availability of food sources and cover. As is known that Sawal Mountain is a tropical rain forest that still has good conditions especially on $500-1500 \mathrm{~m}$ asl, whereas at lower altitudes it is more widely used by the community as agricultural land and fields. This is in line with the vertical distribution of mammals on Slamet Mountain, which is indicated to follow the height pattern of primary and secondary forest [10]. 

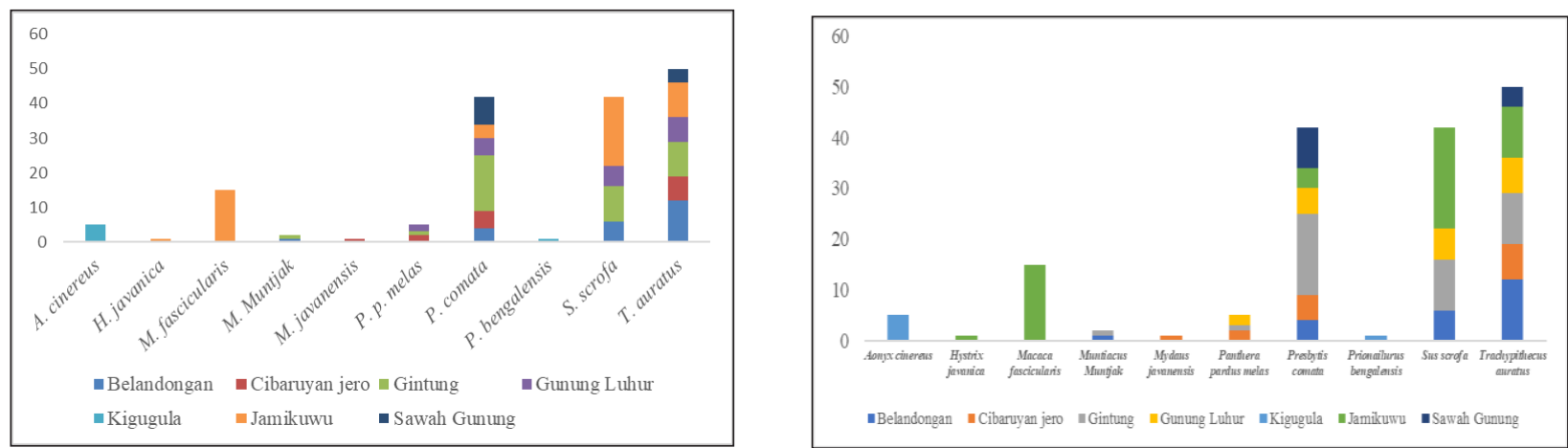

Fig. 4. Distribution and abundance of mammals on Sawal Mountain
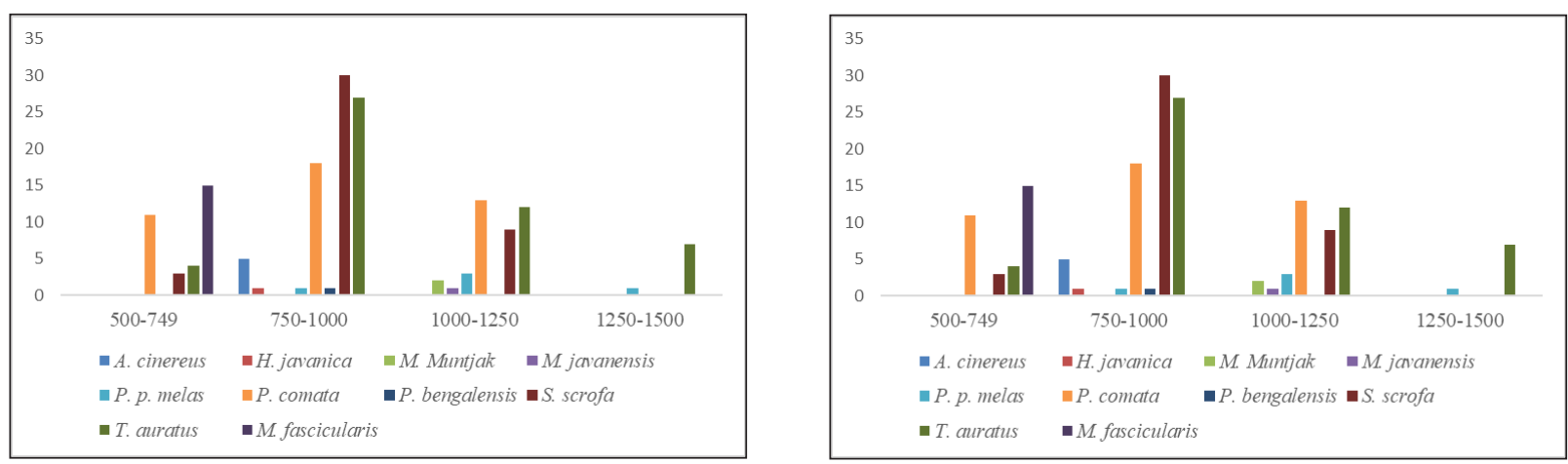

Fig. 5. Distribution of mammals based on altitude

Table 1. List of mammal species on Mount Sawal Wildlife Reserve

\begin{tabular}{|c|c|c|c|c|c|c|}
\hline Family & Ind. Name & Scientific Name & Activity & CITES & IUCN & Indonesian Law \\
\hline \multirow[t]{2}{*}{ Felidae } & Macan tutul & $\begin{array}{l}\text { Panthera pardus melas (G. } \\
\text { Cuvier, 1809) }\end{array}$ & $\mathrm{D} / \mathrm{N}$ & App I & VU & Protected \\
\hline & Kucing kuwuk & $\begin{array}{l}\text { Prionailurus bengalensis } \\
\text { (Kerr, 1792) }\end{array}$ & $\mathrm{D} / \mathrm{N}$ & App II & $\mathrm{LC}$ & Protected \\
\hline \multirow[t]{2}{*}{ Mustelidae } & Sero ambrang & Aonyx cinereus (Illiger, 1815) & $\mathrm{N}$ & App I & VU & Not Protected \\
\hline & Teledu Sigung & $\begin{array}{l}\text { Mydaus javanensis } \\
\text { (Desmarest, 1820) }\end{array}$ & $\mathrm{N}$ & & $\mathrm{LC}$ & Not Protected \\
\hline \multirow[t]{3}{*}{ Cercophitecidae } & Lutung surili & $\begin{array}{l}\text { Presbytis comata (Desmarest, } \\
1822 \text { ) }\end{array}$ & $\mathrm{D}$ & App II & EN & Protected \\
\hline & Lutung budeng & $\begin{array}{l}\text { Trachypithecus auratus (É. } \\
\text { Geoffroy Saint-Hilaire, 1812) }\end{array}$ & $\mathrm{D}$ & App II & VU & Protected \\
\hline & $\begin{array}{l}\text { Monyet ekor } \\
\text { panjang }\end{array}$ & $\begin{array}{l}\text { Macaca fascicularis } \\
\text { (Raffles, 1821) }\end{array}$ & $\mathrm{D}$ & App II & $\mathrm{LC}$ & Not Protected \\
\hline Cervidae & Kijang muncak & $\begin{array}{l}\text { Muntiacus muntjak } \\
\text { (Zimmermann, 1780) }\end{array}$ & $\mathrm{D} / \mathrm{N}$ & - & $\mathrm{LC}$ & Protected \\
\hline Suidae & Babi celeng & Sus scrofa Linnaeus, 1758 & $\mathrm{D} / \mathrm{N}$ & - & $\mathrm{LC}$ & Not Protected \\
\hline Hystricidae & Landak jawa & $\begin{array}{l}\text { Hystrix javanica (F. Cuvier, } \\
1823 \text { ) }\end{array}$ & $\mathrm{N}$ & - & $\mathrm{LC}$ & Protected \\
\hline
\end{tabular}

Note: D: diurnal; N: nocturnal. Status IUCN: EN: Endangered, CR: Critically Endangered, LC: Least Concern, LR: Lower Risk / Near Threatened, VU: Vulnerable, EX: Extinct, EW: Extinct in the Wild, DD: Data Deficient, NE: Not evaluated. App I: Appendix I of CITES; App II: Appendix II of CITES. 
Observation shows that three species namely $P$. comata, T. auratus and S. scrofa are the most common species recorded, especially on $750-1000 \mathrm{~m}$ asl. This relates to the condition of forests that are still quite good. High vegetation density provides suitable habitat for primate species. When compared with the three other primate species, M. fasciculus is relatively more abundant at lower altitudes near agricultural areas, meanwhile, the other two primate species prefer a denser forest habitat. This is affected by the presence of food sources and the nature of the species. As we know that $M$. fascicularis plays an important role in the process of forest regeneration so they are often seen in open and logged-over areas. Gumert et al [15] stated that M. fascicularis are edge species that are often found along rivers in Tanjung Puting National Park. Furthermore, Brotcorne et al [16] also stated that $M$. fascicularis prefer to use sleeping trees that are close to areas of human activity.

Panthera pardus is the top predator was detected based on local community information and also footprints, scratch, and feces. This species is a top predator which is very important for the ecosystem balances, as well as an indicator of habitat quality. On the other side, $P$. pardus also face a lot of pressure due to conflicts with humans $[17,18]$. The herbivorous animals recorded during the observation were $S$. scrofa and $M$. muntjak, both of which are prey of $P$. pardus.

\subsection{Mammals Diversity}

Analysis of diversity shows that Sawal Mountain is in the medium and low categories with Shannon index values ranging from $1-1.5$ (Table 2 ). A diversity index is closely related to species richness and individual abundance of each species. Mammal communities in Sawal Mountain tend to be evenly distributed, but the population of each species is relatively diverse so that it affects the value of the diversity index.

Table 2. Diversity index values for each forest path/block

\begin{tabular}{lccccccc}
\hline Diversity & Bel & Cby_Jr & Gtg & Gu_Lhr & Kgl & Jkw & Swh_Gg \\
\hline Taxa_S & 4 & 4 & 5 & 4 & 2 & 5 & 2 \\
Individuals & 23 & 15 & 38 & 20 & 6 & 50 & 12 \\
Dominance_D & 0,3724 & 0,3511 & 0,3172 & 0,285 & 0,7222 & 0,2968 & 0,5556 \\
Shannon_H & 1,131 & 1,171 & 1,258 & 1,305 & 0,4506 & 1,33 & 0,6365 \\
Evenness_e`H/S & 0,7743 & 0,8064 & 0,7039 & 0,9223 & 0,7846 & 0,7561 & 0,9449 \\
Margalef & 0,9568 & 1,108 & 1,1 & 1,001 & 0,5581 & 1,022 & 0,4024 \\
\hline
\end{tabular}

Jamikuwu and Gunung Luhur have the highest Shannon index values, respectively 1,330 and 1,305, whereas Kigugula and Sawah Gunung are the lowest with values of 0.450 and 0.636 . The diversity of mammal species is linear to the balance of the ecosystem, this is related to the role and function of mammals that are important in maintaining the food chain and the energy cycle in the ecosystem. Several studies have revealed that the mammals naturally acts as a seed disperser, pollinator, controls insect populations and as prey [19-21].

Mammal diversity in Sawal Mountain is also influenced by the community activity around the areas. Diniyati [22] revealed that land conversion in Sawal Mountain still continues, especially in community forest areas. Changes in land use by the community have an impact on the decreasing of forest areas. The loss of forest and trees will directly affect the animals that live arboreal, especially primate groups. On the other hand, agricultural and farming activities that frequently occur around the Sawal Mountain region also directly suppress the population of understorey which is the main feed of various herbivorous. A similar thing was also reported by Sulistyadi [10] that factors of human activity such as forest encroachment, animal hunting, logging, and others contribute to the disruption of wildlife habitat in Slamet Mountain. Furthermore, Husodo et al [11] stated that most species on Java are highly dependent on forests, thus deforestation and land-use change are the main threats to the conservation of its species. The impact of land changes on biodiversity can also be seen from the many reports of animal conflicts around the forest, especially those related to $P$. pardus and $M$. fascicularis. Therefore, attention and efforts from all parties are needed to be able to maintain the sustainability of biodiversity in Sawal Mountain.

\subsection{Clustering Analysis}

Cluster analysis is performed to see the grouping based on species and observation path/forest block with the Euclidean Distance Index. This grouping is influenced by the similarity of characteristics and factors that characterize a species or habitat (Fig. 6). Cluster analysis with the euclidean distance index shows that there are three groups based on species. The first group consisting of $M$. fascicularis and $S$. scrofa which are adaptive species and have a wide range of habitats. That result is in line with Sulistyadi [4] stated that large mammal species in Bali Barat National Park are distributed in various locations and habitat types with dominant species are $M$. fascicularis and S. scrofa. The second group is $P$. comata and T. auratus which are arboreal species, and the third group consisting of species associated with forest habitat.

Cluster analysis based on observation path/forest block shows that there are two groups formed, the first group consisting of Jamikuwu associated with mixed habitats; and the second group consisting of other locations that are more associated with forest habitat. Most of the observation paths associated with the presence of forest habitat indicate that the condition of the forests on Sawal Mountain is relatively good. This result is in line with Maharadatunkamsi [14] which states that the observation plot of small mammals in the Sawal 
Mountain forest is a relatively intact habitat that is shown from the inhabitants of mammals, most of which are species that live in the forest.

\subsection{Conservation Status}

Six species of mammal in Sawal Mountain are protected animals by the Indonesian Law, including $P$. pardus, $T$. auratus, $P$. comata, $H$. javanica, and $P$. bengalensis, and M. muntjak. One species is critically endangered (CR), one species is endangered (EN), two species are vulnerable, and six other species are

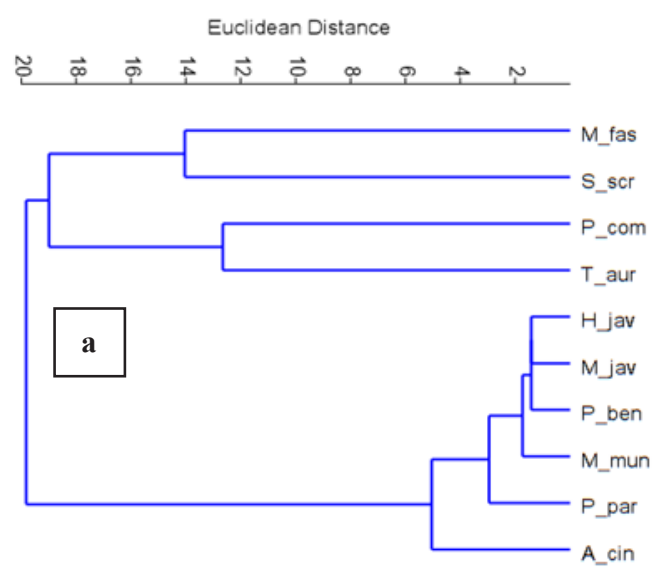

least concern based on The IUCN Redlist of Threatened Species [23]. Trade status based on CITES [24] shows that there are two species classified as Appendix I and four species belonging to Appendix II. The conservation status of mammals in Sawal Mountain is relatively higher when compared to Sulistyadi $^{4}$ which reported that the composition of mammals in the West Bali National Park consists of five protected species, two vulnerable species (IUCN Redlist), and three species including CITES Appendix II.

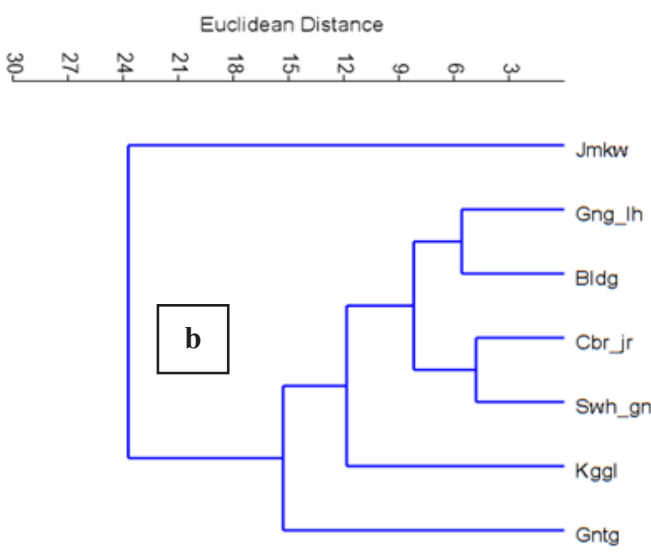

Fig. 6. Cluster analysis based on (a) Mammal Species and (b) Observation Path / Forest Block

Conservation status is related to the level of threat on species. Some species may be able to adapt to changes in habitat and other environmental factors, but this does not necessarily reduce the level of threat to species sustainability. Mustari et al [25] that some species of mammals can still live in fragmented habitats on the IPB University area, but he also concludes that poaching, land conversion, and loss of vegetation were the main threats to the sustainability of mammals in their habitat. The same thing was also reported by Sulistyadi et al [26] that $T$. auratus on Mount Pancar can adapt to fragmented habitats, however, habitat destruction continues to threaten its sustainability. The existence of mammal species that have high conservation status implies the importance of conservation efforts carried out in the Sawal Mountain region.

\section{Conclusion}

Mammal diversity in Sawal Mountain is relatively moderate with an evenly distribution of species in each observation path/forest block. Vertically, most species are found in the altitude range of $750-1000$ meters above sea level. The presence of mammal species that are ecologically important, endangered, and protected shows an indication of the importance of Sawal Mountain in biodiversity conservation efforts in Indonesia
This research is one of the activities funded by DIPA of Research Center for Biology - LIPI. Therefore, on this opportunity, we would like to thank the Head of Research Center for Biology, who supported this research. We would also like to thank KSK Fauna Indicator of Citanduy Watershed Environmental Quality, research field team, and all those who have assisted this research.

\section{References}

1. E. Junaidi, R. Maryani, Jurnal Penelitian Sosial dan Ekonomi Kehutanan, 10(2), 122-139 (2013).

2. M. Cardillo, G. M. Mace, K. E. Jones, J. Bielby, O. R. P. Bininda-Emonds, W. Sechrest, C. D. Orme, A. Purvis, Science, 309, 239-1241 (2005). DOI: $10.1126 /$ science. 1116030

3. J. J. Hellmann, G. W. Fowler, Ecol Appl, 9(3), 824-834, (1999). https://doi.org/10.1890/10510761(1999)009[0824:BPAAOF]2.0.CO;2

4. E. Sulistyadi, Zoo Indonesia, 25(2), 142-159 (2016).

5. C. Jones, W. J. McShea, M. J. Conroy, T. H. Kunz, Capturing mammals. In: Measuring and Monitoring Biological Diversity. Standard Methods for Mammals (D. E. Wilson, F. R. Cole, J. D. Nichols, R. Rudran, M. S. Foster, 
eds), pp. 115-155, (Smithsonian Institution Press, Washington, 1996).

6. G. B. Corbet, J. E. Hill, The mammals of the Indomalayan region; a systematic review. (Natural History Museum Publications, Oxford University Press, 1992)

7. J. Payne, C.M. Francis, K. Phillipps, S.N. Kartikasari, Mamalia di Kalimantan, Sabah, Sarawak, dan Brunei Darussalam, (The Sabah Society Malaysia and Wildlife Conservation Society Indonesia Program, Bogor, 2000)

8. Ø. Hammer, D.A.T. Harper, P.D. Ryan, https://palaeo-

electronica.org/2001 1/past/issue1 01.htm [accessed on 7 December 2019] (2001).

9. Anonim. http://dishut.

Jabarprov.go.id/index.php?mod $=$ manage Menu\&idMenuKiri=473\&idMenu=517) [accessed on 17 October 2019] (2012).

10. E. Sulistyadi, Komunitas Mamalia Besar Gunung Slamet. In: Ekologi Gunung Slamet: Geologi, Klimatologi, Biodiversitas dan Dinamika social (I. Maryanto, M.Noerdjito, T. Partomihardjo, eds), (LIPI Press, Jakarta, 2012).

11. T. Husodo, S. S. Shanida, P. Febrianto, M. P. Pujianto, E. N. Megantara, Biodiversitas, 20(7), 1846-1858

(2019).

DOI:10.13057/biodiv/d200709

A. Purbatrapsila, E. Iskandar, J. Pamungkas, Zoo Indonesia, 21(1), 39-47 (2012).

12. N. Susanti, Jurnal Biologi Indonesia, 4(3), 153165 (2007).

13. Maharadatunkamsi, Jurnal Berita Biologi, 18(1), 1-12 (2019).

14. M. D. Gumert, D. Rachmawan, E. Iskandar, Jurnal Primatologi Indonesia, 9(1), 3-12 (2012).
15. F. Brotcorne, C.Maslarov, I. N. Wandia, A. Fuentes, R. C. Beudels-Jamar, M. C. Huynen, Am J Primatol. 76, 1140-1150 (2014). doi: 10.1002/ajp.22299

16. T. Husodo, P.Febrianto, E. N. Megantara, S. S. Shanida, M.P. Pujianto, Biodiversitas, 20(5), 1281-1288 (2019). https://doi.org/10.13057/biodiv/d200518

17. R. Partasasmita, S. S. Shanida, J. Iskandar, E. N. Megantara, T. Husodo, Parikesit, N. Malone, Biodiversitas, 17(2), 783-790 (2016). DOI: 10.13057/biodiv/d170255

18. R.A. Medellin, Sustaining transboundary ecosystem services by bats. In: Conservation of shared environments learning from the United States and Mexico (L. López-Hoffman, E. McGovern, R. Varady, K. Flessa, eds), (The University of Arizona Press, Tuscon, 2009).

19. Maharadatunkamsi, Potensi mamalia kecil dalam mendukung fungsi lindung Gunung Slamet. In: Ekologi Gunung Slamet. Geologi, Klimatologi, Biodiversitas dan Dinamika Sosial (I. Maryanto, M. Noerdjito, P. Partomihardjo, eds) (LIPI Press, Jakarta, 2012).

20. W.F. Frick, P.A. Heady, A.D. Earl, M.C. Arteaga, P. Cortés-Calva, R.A. Medellín, J. Mammal. 99(50), 1072-1081 (2018). https://doi.org/10.1093/jmammal/gyy088

21. D. Diniyati, S. A. Awang, Jurnal Analisis Kebijakan Kehutanan 7(2), 129 - 143 (2010).

22. IUCN, https://www.iucnredlist.org [accessed on 13 December 2019] (2019).

23. CITES, https://checklist.cites.org/\#/en [accessed on 7 December 2019] (2019).

A. H. Mustari, I. Zulkarnain, D. Rinaldi, Media Konservasi 19(2), 117-125 (2014).

24. E. Sulistyadi, A. P. Kartono, I. Maryanto, Berita Biologi 12(3) (2013). 